\title{
Wiesław Jamrożek
}

Uniwersytet im. Adama Mickiewicza

w Poznaniu

\section{Galicyjska „Krytyka” jako źródło do dziejów edukacji}

Prasa, czasopiśmiennictwo stanowią niezmiernie ważne źródło historyczne, także w badaniach historyczno-pedagogicznych. Nie chodzi tutaj tylko o czasopisma o wyraźnym profilu edukacyjnym czy pedagogicznym, w tym również o pedagogiczne czasopiśmiennictwo naukowe. Dla badań dziejów edukacji niezmiernie przydatna jest też analiza zawartości czasopism i prasy mniej czy bardziej odbiegającej od tego profilu. Interesującego materiału źródłowego dla współczesnego historyka wychowania - choć przy koniecznej dużej ostrożności przy korzystaniu z niego - może dostarczyć zwłaszcza kwerenda czasopiśmiennictwa społeczno-kulturalnego ostatnich dwóch stuleci, na łamach którego obecna była często problematyka edukacyjna. Do tego rodzaju czasopism można zaliczyć także galicyjską, „Krytykę”.

„Krytyka” wychodziła w Krakowie w latach 1896-1914, początkowo jako nieoficjalny organ Polskiej Partii Socjalno-Demokratycznej Galicji i Śląska, następnie jako pismo sympatyzujące z ruchem socjalistycznym w Galicji i z tzw. lewicą niepodległościową. Należy zarazem wspomnieć, że z „Krytyką” współpracowali również liczni autorzy spoza ruchu socjalistycznego ${ }^{1}$.

Była periodykiem (miesięcznikiem) społeczno-kulturalnym, adresowanym przede wszystkim do inteligencji, który po powstaniu w kwietniu 1896 r., po piętnastu miesiącach, został w $1897 \mathrm{r}$. zawieszony. W tym czasie jej redaktorem był Ludwik Bruner (1871-1913), chemik, a zarazem publicysta i literat. Na łamach „Krytyki” pisali wtedy znani socjaliści, jak: Ignacy Daszyński, Leon Wasilewski, Bolesław Limanowski, Felicja Nossig, Feliks Perl. Została wznowiona w roku 1899. W 1901 r. redaktorem pisma został Wilhelm Feldman (8 IV 1868 - 25 X 1919), historyk i krytyk literacki, do którego poglądów odwoływała się część środowiska mniejszości żydowskiej, dążąca do całkowitej asymilacji Żydów, do ich polonizacji. Po 1905 r. pismo kierowane przez W. Feldmana

${ }^{1}$ Zob. m.in.: J. Myśliński, Polska prasa socjalistyczna w okresie zaborów, Warszawa 1982, s. $93,94,179$. 
zbliżyło się do obozu Józefa Piłsudskiego. Wspomniany Leon Wasilewski także znany działacz niepodległościowy, członek delegacji pokojowej w Rydze w 1921 r. - pisał już w Polsce międzywojennej, że Wilhelm Feldman uczynił z „Krytyki” „pismo o niezwykłych walorach ideowych i wysokim poziomie użyteczności społecznej. Stała się ona $\mathrm{z}$ biegiem czasu prawdziwą trybuną polskiej myśli niezależnej i kuźnicą nowych prądów ożywczych. Feldman miał bowiem odwagę dawania w swym piśmie głosu wszystkim tym, którzy by gdzie indziej nie znaleźli miejsca dla wypowiedzenia opinii, przeciwstawiających się utartym poglądom szarej przeciętności”2. W ocenie tego samego autora „Krytyka” stała się w okresie po rewolucji 1905-1907 „najpoważniejszym źródłem systematycznych wiadomości o wszelkich poczynaniach obozu niepodległościowego, a zarazem terenem, na którym poczynania te znajdowały głębokie uzasadnienie i świetną obronę"”. Można również dodać w tym kontekście, że dzięki jej redaktorowi wpisywała się ona w ramy neoromantycznego modelu zaangażowania patriotycznego i społecznego.

Od samego początku na łamach „Krytyki” obecna była problematyka dotycząca emancypacji i edukacji kobiet oraz ruchu kobiecego. Było to konsekwencją radykalizacji emancypujących się środowisk kobiecych na ziemiach polskich na przełomie XIX i XX w. i wejścia $\mathrm{w}$ tym czasie dotychczasowego polskiego ruchu kobiecego $\mathrm{w}$ fazę jego organizacyjnego istnienia. Do roli czołowych działaczek tego ruchu urastały wówczas między innymi: Izabela Moszczeńska, Kazimiera Bujwidowa, Zofia Daszyńska-Golińska, wspomniana wyżej Felicja Nossig, Paulina Kuczalska-Reinschmit, Maria Wiśniewska-Turzyma, Maria Wysłouchowa. Kwestia kobieca (w tym i problematyka edukacji kobiet) podejmowana była na ogólnopolskich zjazdach kobiet. Była także przedmiotem obrad obu galicyjskich (lwowskich) kongresów pedagogicznych (w 1894 i w 1909 r.) ${ }^{4}$. Większość z wymienionych działaczek wypowiadała się na temat tej kwestii również na łamach krakowskiej „Krytyki” (oczywiście obok typowych organów ruchu kobiecego w zaborze austriackim, jak np. „Ster”, „Przodownica”, „Zorza”, „Nowe Słowo”). Z czasem wprowadzono nawet odrębną stałą rubrykę w tym piśmie pt. „Przegląd ruchu kobiecego”, prowadzoną przez Kazimierę Bujwidową (od 1903 r.). Można zatem traktować „Krytykę” jako ważne źródło do poznania ruchu kobiecego na ziemiach polskich $\mathrm{z}$ tego okresu, w tym również jego ideologii i działalności edukacyjnej. Należy zarazem przyznać, że na łamach tego periodyku pisały najczęściej działaczki o tzw. „umiarkowanym usposobieniu" do kwestii kobiecej, przeciwstawiające się rygorystycznemu pojmowaniu przez feminizm zasady równości. Na przykład od początku

\footnotetext{
${ }^{2}$ W. Feldman, Dzieje polskiej myśli politycznej 1864-1914, wyd. II, Warszawa 1933, s. VI.

${ }^{3}$ Tamże.

${ }^{4}$ Zob.: W. Jamrożek, Programy i działalność edukacyjna kobiet polskich okresu niewoli narodowej, [w:] D. Żołądź-Strzelczyk, W. Jamrożek, Studia z dziejów edukacji kobiet na ziemiach polskich, Poznań 2001, s. 134-135.
} 
zabierała głos w „Krytyce” (i nie tylko w kwestii kobiecej) związana z nimi i już wspominana - Zofia Daszyńska-Golińska ${ }^{5}$. Pojawiały się jednak w „Krytyce" teksty także bardziej radykalnych działaczek, jak na przykład Heleny Landau (późniejszej żony czołowego austromarksisty - Otto Bauera).

Na łamach „Krytyki” podejmowano szereg teoretycznych problemów związanych, najogólniej rzecz biorąc, $\mathrm{z}$ wychowaniem. Do jednych z tych problemów należała na przykład kwestia wychowania narodowego. Na ten temat wypowiadała się w piśmie na przykład Iza Moszczeńska ${ }^{6}$. Swoje stanowisko w kwestii wychowania narodowego - odmienne od stanowiska w tej kwestii lansowanego $\mathrm{w}$ łonie obozu narodowego, m.in. przez Zygmunta Balickiego i nawiązujące do jej wystąpienia podczas obrad II Kongresu Pedagogicznego, zaprezentowała na łamach pisma Helena Radlińska ${ }^{7}$.

Pisano również w „Krytyce” o wzajemnych relacjach pomiędzy wychowaniem a religią. Szczególnie żywa dyskusja na ten temat toczyła się na łamach „Krytyki” w 1909 r. ${ }^{8}$ Nie zabrakło także innych złożonych problemów, które i dzisiaj wywołują dyskusje oraz polemiki, jak na przykład zagadnienie wychowania seksualnego'.

Odnotowane zostały w piśmie obrady II Polskiego Kongresu Pedagogicznego, odbytego we Lwowie w dniach 1 i 2 listopada 1909 r. (w tym również powstałe $\mathrm{w}$ toku jego debat kontrowersje, choćby we wspominanej powyżej kwestii wychowania narodowego) ${ }^{10}$.

Charakterystyczne, że w piśmie wprowadzono z czasem (w 1905 r.) odrębną rubrykę, zatytułowaną „Przegląd pedagogiczny”, w której ustosunkowywano się do różnych publikacji traktujących o edukacji i reformie oświaty. Rubryka ta została później zastapiona nowym działem pn. „Ze spraw wychowawczych” (tytułowanym później też: „Ze spraw wychowawczych i towarzystw oświatowych”, „Ze spraw wychowania i oświaty” etc.), redagowanym przez szereg lat przez Helenę Radlińską. Można w tym kontekście wspomnieć, że H. Radlińska (występująca pod pseudonimem H. Orsza) stała się z czasem autorem najczęściej wypowiadającym się w „Krytyce” w sprawach wychowania i oświaty. Sam

${ }^{5}$ Zob. np.: Z. Daszyńska, Znaczenie studiów ekonomicznych dla ruchu kobiecego, „Krytyka” 1896, nr 4; Z. Daszyńska-Golińska, Dokąd daży dzisiejszy ruch kobiecy, „Krytyka” 1901, z. 4; Z. Daszyńska-Golińska, W odpowiedzi feministkom, „Krytyka” 1904, z. 3; Z. Daszyńska-Golińska, O zjeździe kobiet, t. 2, z. XII.

${ }^{6}$ Iza z Moszczeńskich Rzepecka, Nacjonalizm w wychowaniu, „Krytyka” 1904, t. 1, z. 3 it. 1, z. 5 .

${ }^{7}$ H. Orsza, Wychowanie narodowe, ,Krytyka” 1910, t. 1, z. 3, 4, 5 i t. 3, z. 7-8.

${ }^{8}$ A. Baumfeld, Religia w nauczaniu $i$ wychowaniu, „Krytyka” 1909, z. 3; M. A. Walewska, Religia w nauczaniu i wychowaniu, 1909, z. 4, 5; H. Kozicka, Religia w nauczaniu $i$ wychowaniu, „Krytyka” 1909, z. 8-9, z. 10.

${ }^{9}$ S. Kelles-Krauz, Problemat seksualny, „Krytyka” 1910, t. 1, z. 1, 3; W. Zieliński, Młodzież galicyjskich szkót średnich, „Krytyka” 1910, z. 11.

${ }^{10}$ Wł. W., Kongres pedagogiczny we Lwowie, ,Krytyka” 1909, z. 12. 
zaś specjalny dział poświęcony problematyce edukacyjnej ukazywał się w ostatnich latach istnienia pisma pod tytułem „Szkoła i wychowanie”.

„Krytyka” może być interesującym źródłem do rekonstrukcji niedomagań ówczesnego systemu szkolnego oraz polityki oświatowej władz państwowych i krajowych (autonomicznych) realizowanej w zaborze austriackim, także głoszonych w tej dzielnicy - żądań dotyczących reformy edukacji. W pismie dokonywano niejednokrotnie krytycznej oceny ówczesnego systemu szkolnego, domagając się jego przebudowy $\mathrm{w}$ duchu ideałów demokracji oraz nowych treści i idei edukacyjnych, mieszczących się w ramach tzw. nowego wychowania. Zwracano uwagę nie tylko na zapóźnienia Galicji w zakresie szkolnictwa ludowego, ale też i szkolnictwa zawodowego ${ }^{11}$. Podkreślano konieczność reformy szkoły średniej i zakładów kształcenia nauczycieli. Zgodnie z ideami nowego wychowania eksponowano potrzebę szanowania w szkole indywidualności i samodzielności ucznia ${ }^{12}$. W tym kontekście warto nadmienić o zamieszczonej w „Krytyce” recenzji głośnej już wtedy w świecie książki, szwedzkiej pisarki i pedagoga Ellen Key, pt. Stulecie dziecka (która ukazała się na ziemiach polskich w przekładzie I. Moszczeńskiej) ${ }^{13}$. Na łamach „Krytyki” podejmowano także próby oceny wpływów nowego wychowania na polską myśl i praktykę edukacyjną ${ }^{14}$.

W piśmie obecna była również problematyka dotycząca funkcjonowania szkolnictwa wyższego i polskiej nauki ${ }^{15}$.

Zauważając charakterystyczny dla Galicji fakt, że była ona krajem wielonarodowym (u progu XX w. odsetek Ukraińców - „Rusinów” w stosunku do ogółu mieszkańców wynosił $41,5 \%{ }^{16}$ ), w piśmie wskazywano m.in. na niski stopień zorganizowania ukraińskich szkół ludowych, brak takich szkół w miastach i na niedostateczny rozwój ukraińskich szkół średnich ${ }^{17}$. Zamieszczano zarazem głosy wskazujące również na niekorzystne położenie ludności polskiej pod tym względem w Galicji Wschodniej, w regionach, w których stanowiła ona mniejszośćc ${ }^{18}$.

Analiza zawartości „Krytyki” może również dostarczyć wiele ciekawych spostrzeżeń oraz wniosków na temat stosunku środowisk z nią związanych do

${ }^{11}$ Zob. np.: W. Feldman, Dwie kultury, „Krytyka” 1901, z. 10, s. 73; M. Janik, Szkoty galicyjskie w świetle cyfr urzędowych, „Krytyka” 1910, t. 3, z. 11, s. 180.

${ }^{12}$ S., W sprawie młodzieży szkolnej, „Krytyka” 1904, t. 1, z. 6, s. 488, 499.

${ }^{13}$ M. Odrzywolski, Stulecie dziecka, „Krytyka” 1904, t. 2, z. 7.

${ }^{14}$ A. Grudzińska, Z postępów pedologii w Polsce i zagranica, „Krytyka” 1911, t. 3, z. 10.

${ }^{15}$ Zob. np.: dr Lancet, Nauka polska a Uniwersytet Jagielloński, „Krytyka” 1910, t. 2, z. 4, 6, t. 4 , z. $7-8$.

${ }^{16}$ W. Najdus, Szkice z historii Galicji, t. 1, Warszawa 1958, s. 66.

${ }^{17}$ Np. W. Feldman, Rusini i sprawa ruska, „Krytyka” 1902, z. 1; S. Lucki, Kulturalny stan wspótczesnej Rusi galicyjskiej, „Krytyka” 1904, t. 1, z. 1 i t. 1, z. 3; B. Potocki, Kwestia ruska w Galicji i projekt jej załatwienia, „Krytyka” 1908, t. 1, z. 2.

${ }^{18}$ W. Jampolski, Stosunki narodowościowe w szkolnictwie galicyjskim, „Krytyka” 1911, t. 1, z. 1. 
wydarzeń $\mathrm{w}$ edukacji i sytuacji oświaty w innych dzielnicach polskich. Na przykład odnotowane były strajki szkolne w zaborze pruskim, czy bojkot szkoły rządowej w Królestwie Polskim w ostatnich latach panowania rosyjskiego ${ }^{19}$.

Nie zabrakło na łamach „Krytyki” zagadnień dotyczących oświaty pozaszkolnej. Pisano na przykład o potrzebie tworzenia domów ludowych, czytelni, rozwoju ruchu samokształceniowego ${ }^{20}$. Popularyzowano działalność różnych towarzystw oświatowych, w tym także towarzystw aktywnych w innych dzielnicach polskich ${ }^{21}$.

Na łamach „Krytyki” znalazło odbicie również powstanie i rozwój w latach poprzedzających I wojnę światową polskiego skautingu. Należy jednak zauważyć, że na początku wykazywano w tym zakresie dużą nieufność wobec tego ruchu na ziemiach polskich ${ }^{22}$. Później jednak polski skauting był w piśmie w pełni aprobowany i wyrażano opinię, że ,zapoczątkowany ruch pójdzie już szybkim krokiem naprzód"23.

Z powyższego przeglądu wynika, że materiały zamieszczane w „Krytyce” i dotyczące szeroko rozumianej edukacji charakteryzują się wyjątkową rozległością podejmowanej w nich problematyki. Odnoszą się zarówno do praktyki, jak i myśli wychowawczej, przy czym nie tylko w odniesieniu do Galicji. Doskonale ilustrują m.in. spory i dyskusje toczone na ziemiach polskich na przełomie XIX i XX w. na tematy edukacyjne, jak i wzrastające wpływy „nowego wychowania”, rozwijającego się wówczas w światowej myśli i praktyce edukacyjnej. $\mathrm{Z}$ pewnością formułowane $\mathrm{w}$ piśmie oceny i opinie pozostawały pod wpływem idei społecznych oraz zapatrywań politycznych środowisk związanych z pismem, jednak trzeba przyznać, że na ogół cechowało je umiarkowane i racjonalne podejście do tematyki wychowawczej. Uwzględniając to wszystko, można stwierdzić, że „Krytyka” może w konsekwencji stanowić ważne i interesujące źródło do badań dziejów edukacji na ziemiach polskich przełomu XIX i XX stulecia.

\footnotetext{
${ }^{19}$ W tej ostatniej kwestii zob. np.: Sprawa bojkotu szkolnego, „Krytyka” 1914, z. 9, 10.

${ }^{20}$ Zob. np.: K. Bujwidowa, Domy ludowe, „Krytyka” 1903, t. 1, z. 1; W. Feldman, Ta trzecia, „Krytyka” 1903, t. 2, z. 9; H. Orsza, Ze spraw oświatowych, „Krytyka” 1909, z. 6.

${ }^{21}$ Zob. np.: H. Orsza, Z towarzystw oświatowych, „Krytyka” 1907, t. 1, z. 3, 4; T. K. Broniec, Wychowanie i oświata (Refleksje po Zjeździe TSL...), „Krytyka” 1912, t. 3, z. 12.

${ }^{22}$ B. Kostecki, Ruch skautowy w Polsce, ,Krytyka” 1912, t. 3, z. 11.

${ }^{23}$ T. K. Broniec, Szkoła i wychowanie, ,Krytyka” 1913, t. 1, z. 5, s. 288.
} 